\title{
Archaeological Testing of Site 41BX679 Bexar County, Texas
}

Wayne C. Young

Follow this and additional works at: https://scholarworks.sfasu.edu/ita

Part of the American Material Culture Commons, Archaeological Anthropology Commons, Environmental Studies Commons, Other American Studies Commons, Other Arts and Humanities Commons, Other History of Art, Architecture, and Archaeology Commons, and the United States History Commons

Tell us how this article helped you.

This Article is brought to you for free and open access by the Center for Regional Heritage Research at SFA ScholarWorks. It has been accepted for inclusion in Index of Texas Archaeology: Open Access Gray Literature from the Lone Star State by an authorized editor of SFA ScholarWorks. For more information, please contact cdsscholarworks@sfasu.edu. 


\section{Archaeological Testing of Site 41BX679 Bexar County, Texas}

\section{Licensing Statement}

This is a work produced for the Texas Department of Transportation (TxDOT) by the report producer. TxDOT and the report producer jointly own all rights, title, and interest in and to all intellectual property developed under TXDOT's contract with the report producer. The report may be cited and brief passages from this publication may be reproduced without permission provided that credit is given to both TxDOT and the report producer. Permission to reprint an entire chapter, section, figures or tables must be obtained in advance from either the Supervisor of the Archeological Studies Branch, Environmental Affairs Division, Texas Department of Transportation, 125 East 11th Street, Austin, Texas, 78701 or from the report producer. 


\title{
ARCHAEOLOGICAL TESTING OF SITE 41BX679 BEXAR COUNTY, TEXAS
}

\author{
B y \\ Wayne C. Young
}

Texas

State Department of Highways and Public Transportation Highway Design Division

May 1985 


\begin{abstract}
Testing of Site 41BX679 along Farm to Market Highway 2696 in Bexar County, Texas, to determine eligibility for inclusion within the National Register of Historic Places, cultural context, and archaeological significance was undertaken in April 1985. The site is located along a slight rise between Cibolo Creek and Muesebach Creek in northern Bexar County. It has been disturbed by previous construction or cutting of fire lines along Camp Bullis military reservation. Results of testing indicate that 41 BX679 contained a minimal prehistoric component of unknown age. An intact hearth was uncovered but associated lithic debitage was almost totally absent. Evidence recovered does not support a determination of eligibility for inclusion within the National Register of Historic Places.
\end{abstract}




\section{INTRODUCTION}

Archaeological Site 41BX679 was recorded at the Texas Archeological Research Laboratory of the Balcones Research Center, The University of Texas at Austin, in April 1985 by a member of the State Department of Highways and Public Transportation (SDHPT) professional cultural resources staff, Following initial evaluation, further investigation and testing were recommended. On April 24, 1985, the site was tested by Wayne C. Young of the SDHPT professional cultural resources staff.

Testing of Site 41BX679 was performed under the Memorandum of Understanding between the SDHPT and the Texas Antiquities Committee, The object of the test was to determine eligibility for inclusion of the site within the National Register of Historic Places, the nature of the deposits, and the cultural context of the site.

The highway construction project affecting Site $41 B X 679$ provides for the improvement of a county road into Farm to Market Highway 2696. The project involves improving alignments and widening the driving lanes from 20 to 24 $\mathrm{ft}$. The right-of-way which is $120 \mathrm{ft}$. wide has been acquired for the project.

Site $41 B \times 679$ is located about $0.1 \mathrm{mile}$ south of the county line separating Bexar and Comal Counties (Fig. 1). The site is located about midway between Cibolo and Muesebach Creeks along a small rise to the west of Blanco Road. The site limit was difficult to determine as cultural materials consisted of an intact hearth and a single flint flake. Site deposits have been disturbed by road-grader activity which has removed 20 to $30 \mathrm{~cm}$ of soil and has exposed the hearth. The upper and missing soil zones contained a thin mantle of black clay overlying a brown clay loam. The hearth and flake were in the brown soils and lying on brown soils containing calcium carbonate pebbles and small limestone fragments. 
This Page Redacted Per THC Policy 
Site 41BX679 is difficult to describe due to the lack of cultural materials and the previous impacts of construction activities in the area. Surface observations and testing yielded a single flake, an intact hearth (Fig. 2), and an unburned snail shell. The flake and hearth were found in a roadgrader strip and are presumed to have originally been 20 to $30 \mathrm{~cm}$ beneath the present ground surface. The snail was found in the hearth excavation.

The site is located on a small $\mathrm{r}$ ise about midway between Cibolo and Muesebach Creeks and is almost 0.1 mile south of Cibolo Creek and .25 mile north of Muesebach Creek. Cibolo Creek has an extensive floodplain immediately east of the site, with the site locale being about $20 \mathrm{ft}$. higher in elevation. The closest permanent water source appears to be Cibolo Creek as Muesebach Creek is an ephemeral stream that is normally dry.

Soils exposed in the road-grader profile consist of a thin black clay zone typical of the Texas Hill Country, with numerous unburned limestone rocks and gravels and extending to an average depth of $8 \mathrm{~cm}$. Beneath this zone was a brown clay loam extending to 20 to $30 \mathrm{~cm}$ beneath the present surface. This zone contained fewer rocks than the surface zone. The feature and single flake recovered were lying at the bottom of the brown clay zone and occurred on top of a lighter brown clay with numerous calcium carbonate and limestone fragments. 


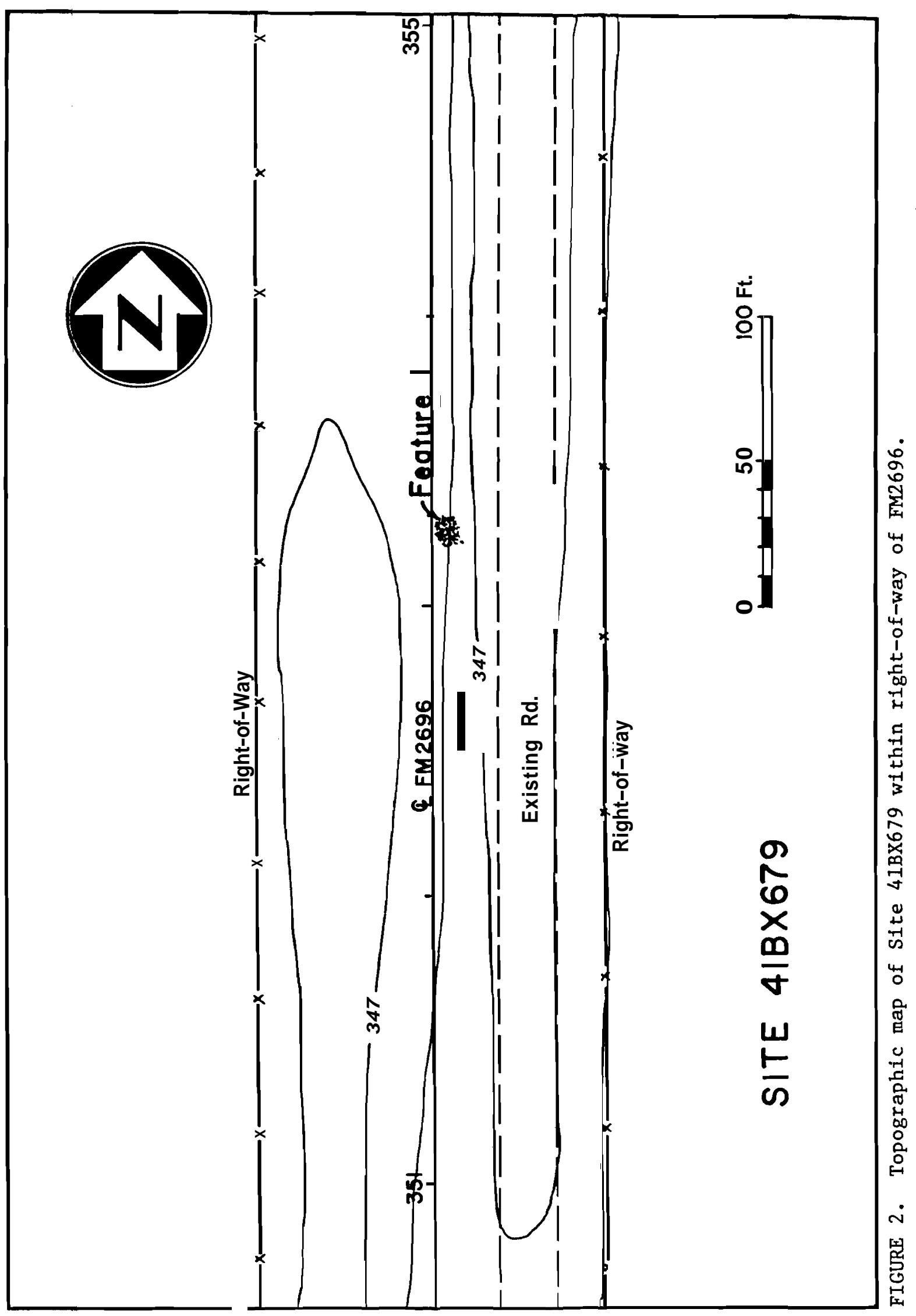




\section{TESTING OPERATIONS}

Archaeological testing of Site 41BX679 consisted of surface observations and the hand-excavation of the exposed hearth. Testing procedures began with a thorough surface examination to locate the hearth reported in the survey and to define the limits of the site.

Surface examinations included a swath down the road-grader cut for about 150 meters on each side of the hearth, an examination of the edges of the cut, and a surface survey of intact areas immediately adjacent to the right-of-way on the Camp Bullis military reservation. Although surface visibility was excellent in all examined areas, only 1 flake was found and it was about 75 meters south of the partially exposed hearth in the grader cut. It should be mentioned that no cultural materials were observed on the undisturbed surface or in the profiles created by the machinery.

Testing consisted of carefully uncovering the burned limestone hearth and documenting and photographing it. An area about 2.5 meters in diameter was carefully troweled and all rocks were left in place. The vertical limits followed the depths of the rocks in the hearth and varied from 1 to $8 \mathrm{~cm}$. Excavated soil was passed through .25 in. mesh hardware cloth screens and resulted in the recovery of a single Rabdotus snail shell.

Once the hearth was fully exposed, it became obvious that the feature was a tightly packed circular hearth with a diameter of 2 meters and a thickness of 5 to $8 \mathrm{~cm}$. Several limestone rocks show in situ fracturing. The obvious patterning (Fig. 3) suggests human construction and the depth (20 to $30 \mathrm{~cm}$ below the surface) suggests a prehistoric affiliation.

The lack of cultural material at the site suggests a very short-term occupation. The lack of materials above and around the feature also indicate a minor occupation. 


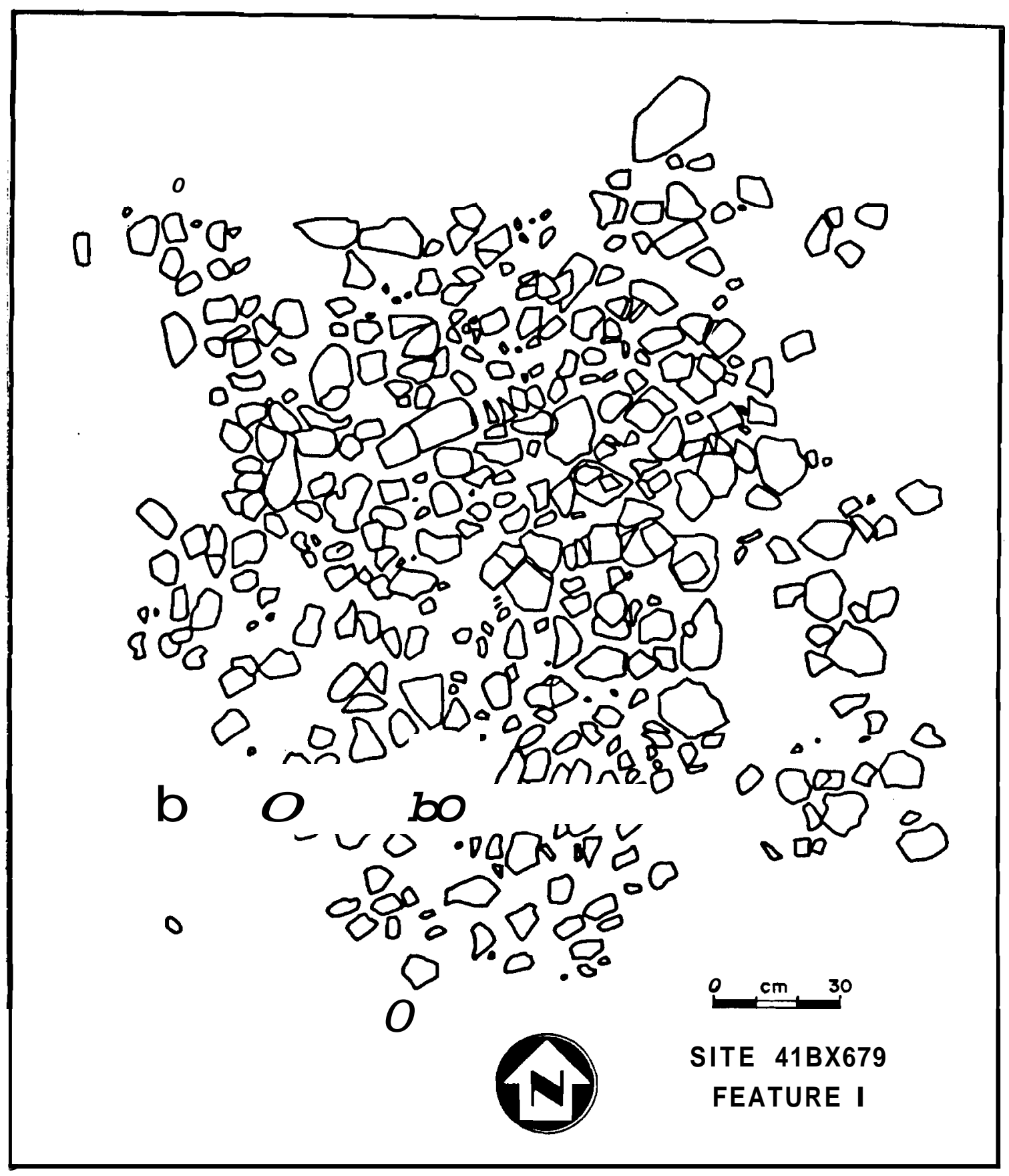

FIGURE 3. Plan view of Feature 1, Site 41BX679. 


\section{CONCLUSIONS AND RECOMMENDATIONS}

Archaeological testing of Site 41BX679 has established that the site has been heavily damaged by past construction activity including the use of a road grader across the site. Although an intact feature was found at the site, the lack of cultural materials suggests that either the site has been totally destroyed or that a very short-term occupation was present which lacks the materials to yield valid information about the site.

It is believed that the portion of Site 41BX679 within the right-of-way does not meet the criteriafor inclusion within the $\mathrm{N}$ ational Register of $\mathrm{H}$ istoric Places. No further investigation at Site $41 \mathrm{~B} \times 679$ is recommended. 